\title{
論文 お。ひ報告
}

\section{Al の MIG 熔接条件に関する一報告*}

— $5 \mathrm{~mm}$ 板の隅肉熔接—

内田

彰**

\section{A Study of Welding Variables of MIG Arc Method*}

- T-fillet Weld of $5 \mathrm{~mm}$ Thick. Al Plate -

By A. Uchida**

\begin{abstract}
In the welding experiment of $\mathrm{T}$-fillet weld of $5 \mathrm{~mm}$ thick aluminum plates, the penetrations, deformations and leg lengths were plotted with $I / \sqrt{v}$ or $\sqrt{I / v}$ as parameters in abscissas. In order to obtain the most reasonable welding schedule we must consider it under the defining factors and limits shown in Fig. 9. In our case, using $1 / 16^{\prime \prime} \phi$ electrode wire, the comparatively high current range $(I=240-280 \mathrm{~A}$, $\left.v=70-110 \mathrm{~cm} / \mathrm{min}, I / \sqrt{ } v=0.20-0.22 \times 10^{3} \mathrm{~A} /(\mathrm{cm} / \mathrm{sec})^{1 / 2}, l=4.5-5.5 \mathrm{~mm}\right)$ is considered preferable.
\end{abstract}

\section{I まえがき}

筆者等はさき江 MIG 熔接法による酎食性 $\mathrm{Al}$ 合金の薄 板についての撘接試験を行ったがリ，それにひきつぶいて T型隅肉熔接须いて若干の試験を行った. 一般飞 MIG 熔接法についてはすでに多くの試験研究がなされたが，乙 かしこれらを概観するならば，最む合理的てして良い熔接 結果を得しとするには，な括二三の検討されるべき問題点 が残っているように思われる。すすなる，種々の文献等に 示された例を比較参照してる，それから知られる撘接条件 には若干の币があって，此較的大きな電流と早い熔接速度 また忙々の反対との二様の撰択の可能性がみられる. 自動 燃接に括いては熔接速度は，それだけを切り離してい古 ば，かなり広い範囲変化することができる．徉って熔接 条件としては単飞焀接電流や燃接速度の経験的数值を与之 るだけでなく，燃接速度と售接電流を組にした変数に対し て愹接結果かどのようになるかるなるへく組織的炕検討す ることが望ましいと思われた。

また MIG 焀接は，殊飞電流が大きい場合には特徽的な 形状の梁い熔込を有するととが知られている22. 従って隅 肉熔接のような場合，一種の深跲込熔接という考壳でやっ た方がよいのかどうかというととも，一般検討されるべ き一つの問題であるろ.

以下の試験はさし当り $5 \mathrm{~mm}$ 厚の一種類の板に限られて 和り，未だ広沉なものではなが，以上の見地で一店若干 のデータを得ること努めたむのである.

* 原稿受付 昭和33年 7月31日（昭和33年度熍接学会 秋季学術講演会江招いて発表)

** 正員, 鉄道技術研究所 Member, Railway Technical Research Institute.

\section{II 熔接結果に影響する諸変数に対す る考察}

熔接の質的な問題を別とすれば，熔接の結果を規定する あのは熔着金属の大きさおよび形状，ならびそ母材の変形 一隅肉では主て収縮と角変化またはやせ馬—てであ. 鋼 の普通の焀接の場合, 熔込深さ，ビード巾，角変化，横収 縮等については渡包教授等 3 )，4の詳細な研究があり，すべ て $(I / \sqrt{v})$ の函数で表わされることが示されている. また 山内氏等 ${ }^{5}$ 《理論的考察と多くの実験結果を吟味して，角

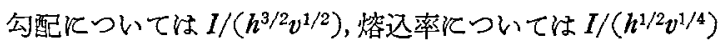
または $I /\left(h v^{1 / 2}\right)$, 镐着重量については $I / v^{1 / 2}$ をパラメー ターとして実験を整理できるととを示している.

従って筆者等は MIG 法浮よるアルミニウムの隅肉㮫接 に括ける横収縮，やせ馬，とけ込等を測定して $I / \sqrt{ } \bar{v}$ をパ ラメーターとして結果を整理してみるととを一つの目標と した。 をた本試験で江電極線の太さが一種類に限られてい

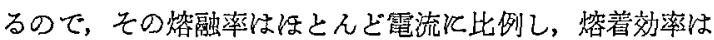
100\%近いから，单位時間の焀着量はIK比例し，従って 脚長招よびのど厚は断面形状が汪よ゙相似と仮定すれば， $(I / v)^{1 / 2}$ 飞比例すべきである.

渡辺教授の研究によれば一般の場合の燃込みは

$$
d / h=\mathrm{J} \frac{l / h}{(\boldsymbol{v} h)^{1 / 2}} \text { で表わされるが, 深塔込棒では, }
$$

$d / h=\mathrm{J} \frac{\mathrm{I} / h}{(v h)^{1 / 2}}+\alpha$ となることが晢摘されている.（熔接協 会ディープフィレット委員会で出した式で $\mathrm{Pu}=\mathrm{a}+\mathrm{b} v$ $+\mathrm{cI} / \sqrt{v}, \mathrm{Pu}$ は \$4. Fig. 6 中の $P s^{\prime}$ と同し。) 他方 $\mathrm{MIG}$ 熔接で特殊な熔込断面形状を有することが既化知られて いるが，特炕の “finger-type penetration” は電極加ら 高速でとび出す小揢粒のいかね゙射撃によって熔融池表面が 
押し下げられる結果であることを，鍓の場合について A. R. Muir ${ }^{6)}$ が指摘して扔り，末たこの部分は燃着金属と母 材との混合が均一でないとと，招よび鍋では脱酸が完全で あ，この部分には気孔を生じ易いことが示されている。

MIG 熔接ておいてはある種の小気孔は避忖難いとみら れているが（たら゙し最近塩素ガスによってそれを除き得る という報告がでた), Houldcroft 等》恃速い焀接速度を用 いて氛孔を微小な分散したものにとがめることを推棌して

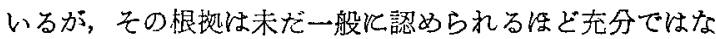
いょうである．本試験では後述のょうに，気泡性について はああり成績がよくなかったが，一応 Houldcroft ${ }^{9)}$ の空 隙㳯の評価法にならったやり方で評価を試みた。 アーク䉓 压についてはさらに別途飞考党るべき変数であるが，本報 告ではそこまでは及えでいない。

\section{III 試 験 条件}

母材は市販 2S 材（一部 3S）の $5 \mathrm{~mm}$ 板であり Fig. 1 のような大きさとし，またガンを固定して試料を移動する ために Fig. 2 飞示したような真鍮製の車付き熔接台飞拊 束具を用いて拘束した (flat position). 熔加電極線はす心゙ て 2S 1/16"巾を使用したが，この太さのものに対する焀 接電流の実用的下限は $130 \mathrm{~A}$, 上限は $300 \mathrm{~A}$ である ${ }^{2), 83}$. またアルゴン流量も $40 \mathrm{cfh}$ (1/2" ノズル使用) の一定と した，熔接装置は前報〉之全く同様のものである.

種々の文献のデータ括よひ電極烨融量の测定結果 ${ }^{8}$ を参 考にして，計画試験条件として Table 1 のよう飞撜えだ.

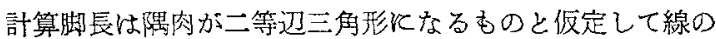
蛒融量から計算したものであり，アーク電王は 23〜24V を標準とした，熔接速度の值が端数であるのはストロボに

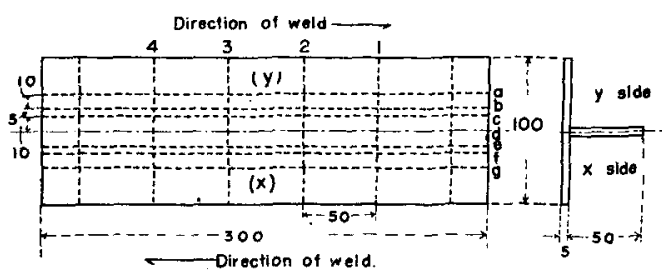

Fig. 1 Size and signification of the plate to be welded in the test

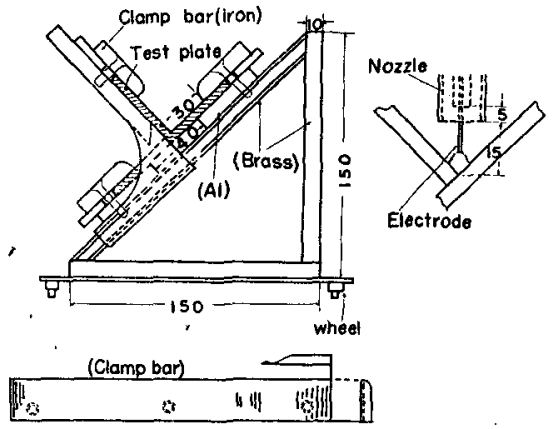

Fig. 2 Jig and fitting for welding test

よって速度を監視したからで，それぞれ使用したストロボ 放射線の11本，14本，18本，23本，28本等飞対応している。

試験板上のガンの高さは Fig. 2 亿示した通りである. 電極線《はリールのくせがあるから尖端が正しい熔接線を 離れないためには，笑出長さをなるべく短く排ぶことが必 要であった。 またその尖端の延長は板の棱線汇向うょうと して行った．垂下特性の熔接機を使用するため，実際行行 われた揢接条件は Table 1 とは僅か異なっている. 試料 数は 2S 材18組 (No. 1-18)，3S 材 3 組 (No. 20-22) で

Table 1 Planned Welding Schedule for the Experiment (Al-2S, $5 \mathrm{~mm}$ Plate \& 1/16" $\phi$ Wire, T-fillet, Flat Positioned). Figures in ( ) show test specimens' numbers.

\begin{tabular}{|c|c|c|c|c|c|c|c|c|c|c|c|c|}
\hline & \multicolumn{12}{|c|}{ Estimated leg length $(\mathrm{mm}) \&[I / \sqrt{v}]\left(10^{3} \mathrm{~A} /(\mathrm{cm} / \mathrm{sec})^{1 / 2}\right)$} \\
\hline Current & \multicolumn{2}{|l|}{$140 \mathrm{~A}$} & \multicolumn{2}{|c|}{$170 \mathrm{~A}$} & \multicolumn{2}{|c|}{$200 \mathrm{~A}$} & \multicolumn{2}{|c|}{$230 \mathrm{~A}$} & \multicolumn{2}{|c|}{$260 \mathrm{~A}$} & \multicolumn{2}{|c|}{$300 \mathrm{~A}$} \\
\hline $\begin{array}{l}\text { Welding Wire feed } \\
\text { speed } v\end{array}$ & $\mathrm{C}=111 \mathrm{~mm}$ & $\mathrm{~m}^{3} / \mathrm{s}$ & $\mathrm{E}=131 \mathrm{~mm}$ & $\mathrm{~m}^{3} / \mathrm{s}$ & $G=158 \mathrm{mn}$ & $\mathrm{n}^{3} / \mathrm{s}$ & $1 \frac{1}{2}=182 \mathrm{~m}$ & $\mathrm{~m}^{3} / \mathrm{s}$ & $\mathrm{K}=210 \mathrm{n}$ & $\mathrm{m}^{3} / \mathrm{s}$ & $\mathrm{L}=240 \mathrm{~m}$ & $\mathrm{~m}^{3} / \mathrm{s}$ \\
\hline $112 \mathrm{~cm} / \mathrm{m}=1.867 \mathrm{~cm} / \mathrm{s}$ & & & & & & & & & $\begin{array}{c}4.74 \\
{[0.190]}\end{array}$ & (21) & $\begin{array}{c}5.08 \\
{[0.219]}\end{array}$ & $(20)$ \\
\hline $88.6 \mathrm{~cm} / \mathrm{m}=1.476 \mathrm{~cm} / \mathrm{s}$ & & & $\begin{array}{c}4.21 \\
{[0.140]}\end{array}$ & & $\begin{array}{c}4.62 \\
{[0.165]}\end{array}$ & $(6)$ & $\begin{array}{c}4.96 \\
{[0.190]}\end{array}$ & $\left.\begin{array}{l}(7) \\
(16)\end{array}\right)$ & $\begin{array}{c}5.33 \\
{[0.214]}\end{array}$ & $\begin{array}{l}(8) \\
(17)\end{array}$ & $\begin{array}{c}5.70 \\
{[0.247]}\end{array}$ & (18) \\
\hline $68.6 \mathrm{~cm} / \mathrm{m}=1.142 \mathrm{~cm} / \mathrm{s}$ & & & $\begin{array}{c}4.79 \\
{[0.159]} \\
\end{array}$ & ( 5$)$ & $\begin{array}{c}5.26 \\
{[0.187]} \\
\end{array}$ & $\begin{array}{r}(3) \\
(13)\end{array}$ & {$\left[\begin{array}{c}5.65 \\
{[0.215]}\end{array}\right.$} & $\left.\begin{array}{l}(4) \\
(14)\end{array}\right)$ & $\begin{array}{c}6.05 \\
{[0.243]}\end{array}$ & (15) & & \\
\hline $53.6 \mathrm{~cm} / \mathrm{m}=0.894 \mathrm{~cm} / \mathrm{s}$ & & & $\begin{array}{c}5.41 \\
{[0.180]}\end{array}$ & $\begin{array}{l}(1) \\
(10)\end{array}$ & $\begin{array}{c}5.95 \\
{[0.212]} \\
\end{array}$ & $\begin{array}{l}(2) \\
(11)\end{array}$ & {$[0.243]$} & $\begin{array}{l}(9) \\
(12)\end{array}$ & & & & \\
\hline $44.3 \mathrm{~cm} / \mathrm{m}=0.738 \mathrm{~cm} / \mathrm{s}$ & $\begin{array}{c}5.53 \\
{[0.163]}\end{array}$ & $(22)$ & $\begin{array}{c}6.15 \\
{[0.198]}\end{array}$ & & & & & & & & & \\
\hline
\end{tabular}


Table 1 中に記してあるが, ほかに若下の予備試験も行っ た.

試験材料の前処理については, 板は普通の方法でアルカ リ洗滌をしたほか，熔接前にブラッシングを行った．電極 線は Airco 製品 2S. c-finished で, 熔接前飞四塩化炭素 ペンヂン, 脱脂綿で払拭したが, 数年間保存されていたも のであったためか, 処理不充分の感があり, そのため後の 結果飞記すように気孔のや〉多い燃接になったものと思わ れる.処理については例党ば鈴木氏等の研究10) (ANP 材) そ詳しいが，本試験では特飞檢討はしなかった。

\section{IV 試 験 結 果}

\section{(1) 外 観}

外観写真の一例を Photo. 1 に示した. この試験では隅 肉は必ずしも常には等脚的飞いかなかったが，これは電極 尖端が時々熔接線をはづれた〉めであって, flat 位置では

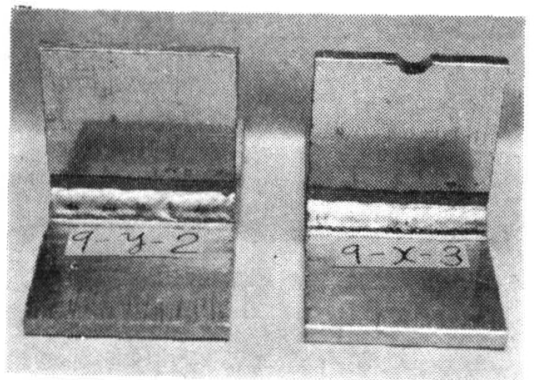

(a) $I=225,220 \mathrm{~A} ; v=53.6 \mathrm{~cm} / \mathrm{min}$

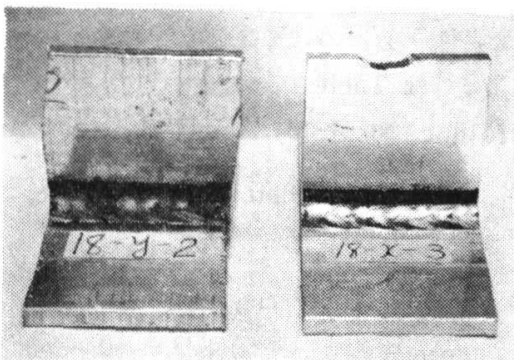

(b) $I=297,300 \mathrm{~A} ; v=88.6 \mathrm{~cm} / \mathrm{min}$

Photo. 1 The weld appearances of some specimens

電極尖端が板の棱線に向くようとしたこと自体は罗当であ るようと思われた.

Table 1 飞颃いて $I / \sqrt{ } v<0.18 \times 10^{3}$ (アーク電厎 $20 \mathrm{~V}$ では約 $0.17 \times 10^{3}, 25 \mathrm{~V}$ では $0.185 \times 10^{3}$ (それぞれ No. 10 および No. 13)）では熔込が不充分であり，ビードが丸く かつ不整になって不適当であった．また電流 $300 \mathrm{~A}$ ではし ばしば大きな吹穴を生じたそそれらの間の条件では概ね良 好な形状の隅肉が得られたが，われわれの場合，一般に表 面気泡がや〉多く生じた，黒粉その他は，例えば Needham 等2)のビード試験による報告に附け加えるべきものは ない,
(2) 変 形

a) 収 縮

Fig. 2 飞示したような拘束は招さえ板の切溝が熔接に直 角方向であった〉め, 収縮に対しては必ずしも拘束が完全 ではなかった憾があるが，相対的傾向を調べるには大過な いと考学られる. Fig. 1 中飞示したような各嚡書線間の距 離を 1，2，3の各 横断線に沿って熔接 前後にコンパレータ 一で測定した. 一例 を Fig. 3 に示した が, 収縮の大部分は $\mathrm{c}$ - e 間で起り, b$\mathrm{c}, \mathrm{e}$ - $\mathrm{f}$ 間でな㨷 か収縮があり, a-b, f一g 間では逆にき わめて僅か伸びを示 している。また 1 、

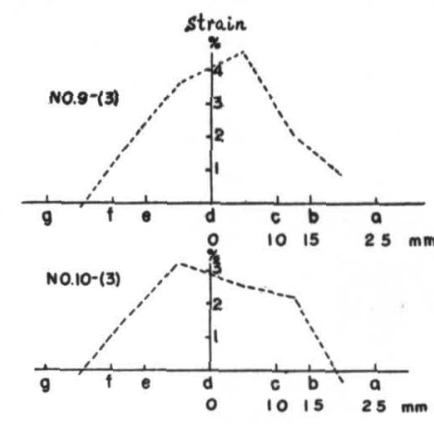

Fig. 3 Contraction of the welded base plate
2, 3 の各位置での収縮はほとんど同じときもあり,かな り違っているときもあり, その変化は一定の傾向はない. そこでこの試験では $\mathrm{b}-\mathrm{f}$ 間の収縮量を $1,2,3$ のう の位置で測定した平均をもって横収縮量としてこれる縦軸 そ，I/ $\sqrt{v}$ を横軸にとってプロットしたグラフを Fig. 5 と示してある.

\section{b) やせ馬 (角変化)}

定盤上のダィヤルゲーヂを滑らせて, 板の曲り変形を測 定した例は Fig. 4 の如くである. 材料の節約のために板 巾がや〉足りないきらいはあるが, 細部の問題はさておい て，本試験では b-f を結ぶ線から d までの高さをとって

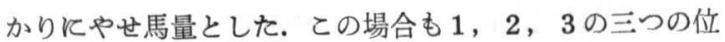
置における平均をとり a) と同様にして Fig. 5 に示した.

(3) 熔込, ビード断面形状

前の試料の羁書線 1，2，3の各位置で切断研磨し，断 面形状を調ぺた。熔込形状の代表的なものは例えば，Fig， 6 飞示す如くであって, 熔込深さとしては四中の $P s_{1}$, $P s_{2}, P s^{\prime}, P b_{1}, P b_{2}, P r$ 等をとることができる. 実際には R

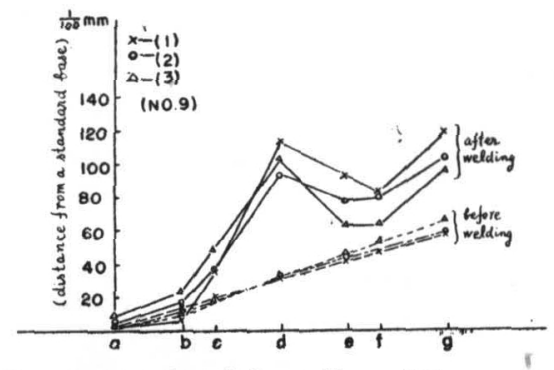

Fig. 4 Angular deformation of the welded base plate 


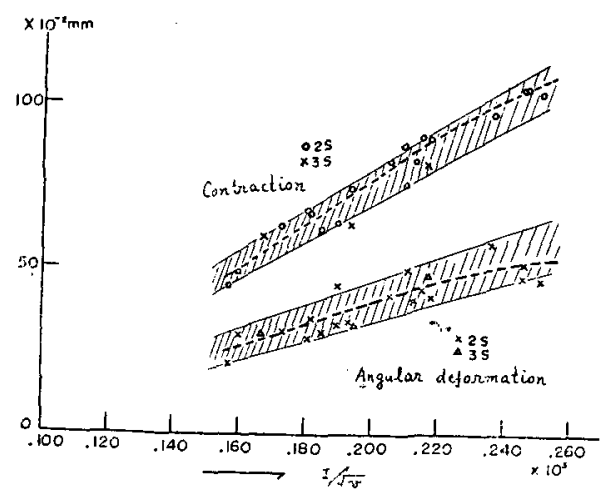

Fig. 5 Contractions and angular deformations of the welded base plate plotted with the parameter $(I / \sqrt{ } v)$

点の位置が明 瞭には定め難 いことや, 酒 側の脚長が完 全佀等しくな るようにする ことは困難な のでこれらの 単独の值には 誤差あるいは バラツキが入

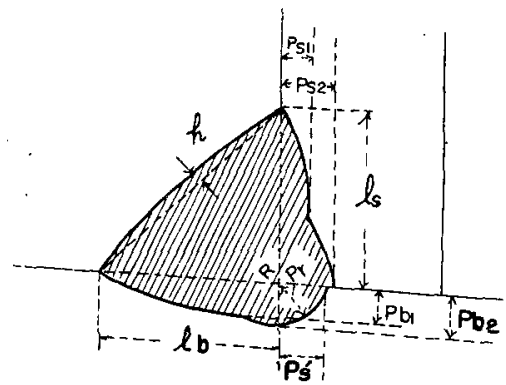

Fig. 6 Typical profile of fillet weld by MIG arc welding りやすい.

Fig. 7 (a) (b) は $1 / 2\left(P s_{1}+P b_{1}\right)$ と $\operatorname{Pr}$ の実测結果を $I / \sqrt{v}$ に対してプロットしたものである. 前者は比較的心 ラツキが少く，この籁囲で㥀線近い関係であることが 認められるが，後者はバラッキがひどくて $I / \sqrt{v}$ をパラ メーターとして表すのは不適当であることが判る. 促って 試みに $I, I^{2} / \sqrt{v}$ 等をパラメーターとしてプロットした結 果，これらの中では $I^{2} / \sqrt{v}$ によるのが最もバラッキが少 いことが判明した. (Fig. 7-(c))。たょ゙前述のように $P r$ の測定自体に少しあいまいさがあるから，な蛒险味の余地 は少くないかもしれない。をた $300 \mathrm{~A}$ の点だけがとび離 れているのは，5 mm 板に対してはこのような深い跲入で は襄面，すなわら板厚の影響を考完なければならないから 他と同様に扱えなくなるのは当然であるう。

次飞隅肉の実際の脚長であるが，ふくらみのために前に 示した計算値 $\left(l=0.402(I / v)^{1 / 2} \mathrm{~mm}\right)$ より小さくなるとと は当然であるが，実験範囲では $I / \sqrt{v}$ のごく小さい所を

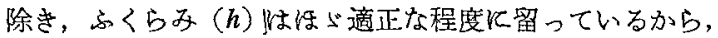
Fig. 80 よう飞 $(I / v)^{1} /^{2}$ と大体直線関係を維持してい る.この直線から下へ著しく離れている点は $I / \sqrt{v}<0.18$ $\times 10^{3}$ のものである.な括 $\mathrm{P} 1.2$ と 3 はそれぞれ隅肉の横 断面怙よび縦断面のマク口写真 (HF 府蝕) の数例を示し
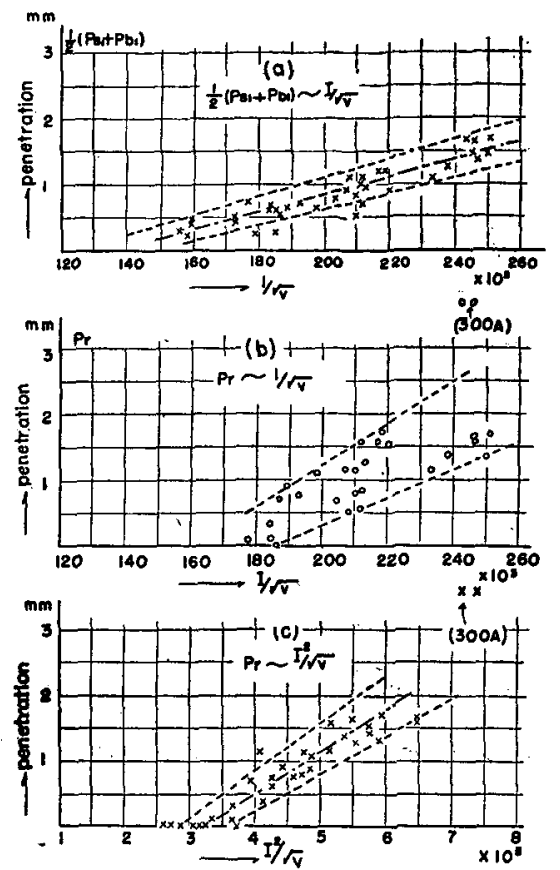

Fig. 7 Penetrations plotted with $I / \sqrt{v}$ or $I^{2} / \sqrt{v}$ as abscissas

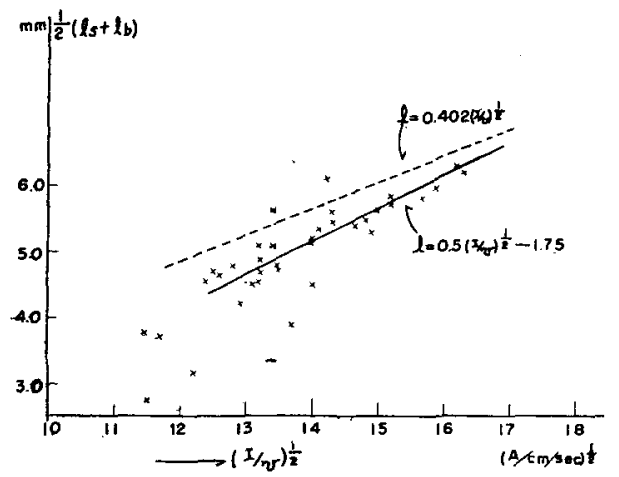

Fig. 8 The measured mean leg-lengths of the fillet welds plotted with $(I / v)^{1 / 2}$

たすのである。

(4) 気孔性

気孔性の評価は， Houldcroft 等のやり方泉にならい， さらに簡巣のために気孔の大きさの分類を 5 種類飞留め (Table 2), 次式尤って「空临率」を求めた.

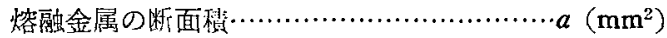

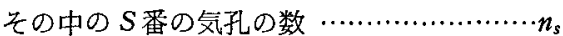

単位容秒中の $S$ 番の気孔数 $\cdots \cdots \cdots \cdots \cdot N_{s}=n_{s} /\left(d_{s}{ }^{\prime} \cdot a\right)$

$S$ 番の気孔の容積 $\cdots \cdots \cdots \cdots \cdots \cdots \cdot V_{s}=\pi / 6 \cdot d_{s}{ }^{3}\left(\mathrm{~mm}^{3}\right)$

空隙率 $(\%$ Voids $)=\sum N_{s} V_{s} \times 100=n_{s} / a \cdot\left(\pi / 6 \cdot d_{s}{ }^{2}\right) \times 100$

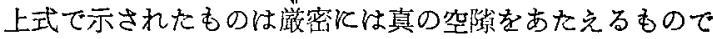
はないが，一-のの評価の尺度として使い得るものと考えら 
Table 2 The Classification of Pores

\begin{tabular}{c|c|c|c}
\hline \hline Size No. & $\begin{array}{c}\text { Range of } \\
\text { diameter }\end{array}$ & \multicolumn{2}{|c|}{ Index for calculating \% voids } \\
\cline { 1 - 4 } \cline { 4 - 4 }$S$ & $d_{s}(\mathrm{~mm})$ & $d_{s}^{\prime}$ & $\pi / 6\left(d_{s}{ }^{\prime}\right)^{2}$ \\
\hline 1 & $0.05 \sim 0.14$ & 0.1 & 0.0052 \\
2 & $0.15 \sim 0.24$ & 0.2 & 0.0209 \\
3 & $0.25 \sim 0.34$ & 0.3 & 0.0471 \\
4 & $0.35 \sim 0.44$ & 0.4 & 0.0834 \\
5 & $0.45 \sim 0.54$ & 0.5 & 0.1308 \\
\hline
\end{tabular}

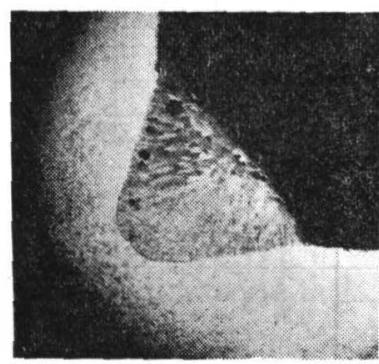

(a) 193A, $23.3 \mathrm{~V}$ : : $v=53.6 \mathrm{~cm} / \mathrm{min}$ (No. 11-y-1)

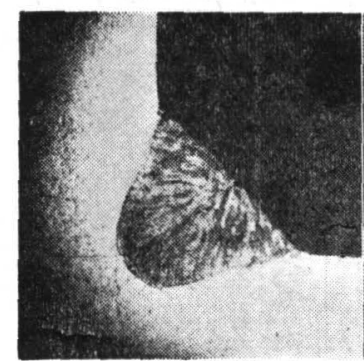

(c) $240 \mathrm{~A}, 23.6 \mathrm{~V}$ $v=88.6 \mathrm{~cm} / \mathrm{min}$ (No. 16-y-1)

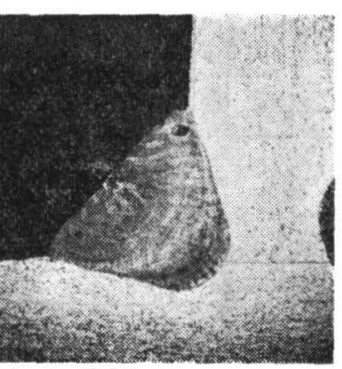

(b) $235 \mathrm{~A}, 22.8 \mathrm{~V}$ $v=88.6 \mathrm{~cm} / \mathrm{min}$ (No: $7-\mathrm{y}-3$ )

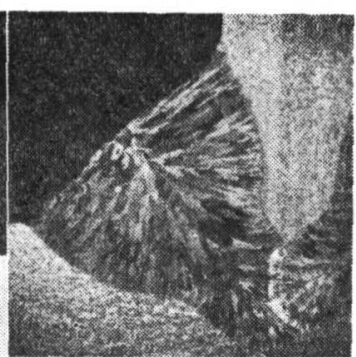

(d) $297 \mathrm{~A}, 24.7 \mathrm{~V}$ $v=88.6 \mathrm{~cm} / \mathrm{min}$

(No. 18-y-3)

Photo. 2 The typical macro-sections of the fillet welds

れる。

本試験では前に述べたようと線材の前処理が不充分であ ったと思われるため, 比較的気泡が多く，かつ試料数が多 くないため, 熔接条件との間飞系統的な関係を求めるには 不適であった. 実測の結果は, 空隙率は小さいもので約 $0.5 \%$ (No. 15-x), 最大で約 5\% (No. 4-x) であり, 大部 分は約 1 2\%であった. 気孔の所在はサイズ番号 1 また はとれ以下はほよ゙全面に分散して抢り，サイズ $2 ， 3$ 等は 表面飞近い部分または母材との境に近い部分飞多く， 3, 4, 5 等の大きなるのは Toe 飞近い部分飞多く生じた。 (Photo. 2(a) 参照) またしばしばルート部に気孔恐らく管 状を生じるのが見られた。また熔接条件との関係沉つてて みるとーとれは試料数が少いため不確ではあるがー200〜 $240 \mathrm{~A}$ ではサイズ番号 4，5等が少くなく，または 160〜 $180 \mathrm{~A}$ 又は 240〜280A すなわち比較的低い電流かまたは

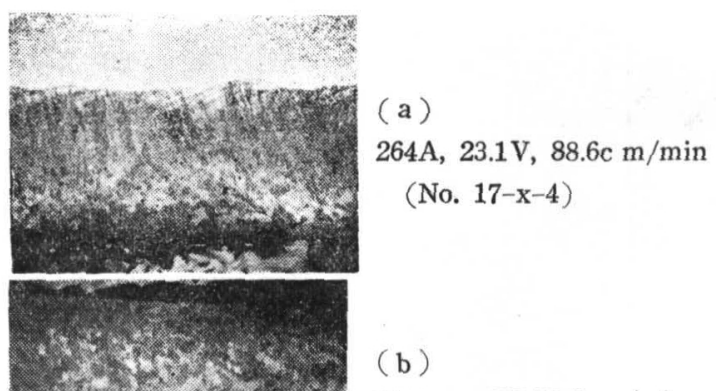

$300 \mathrm{~A} 25.0 \mathrm{~V} 88.6 \mathrm{~cm} / \mathrm{min}$ (No. $18-\mathrm{x}-4$ )

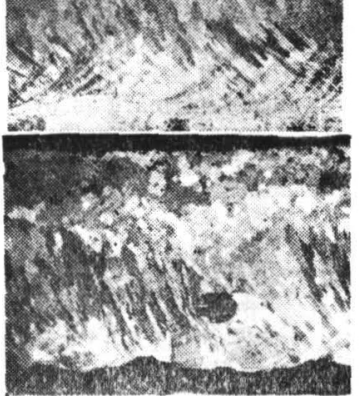

(c)

$296 \mathrm{~A} 24.7 \mathrm{~V} 112 \mathrm{~cm} / \mathrm{min}$

$\left(\begin{array}{l}\text { No. } 20-\mathrm{y}-4 \\ \text { Plate-3S }\end{array}\right)$

Photo. 3 The longitudinal macro-sections of deep fillet specimens

比較的高い電流のいられかかの方が大きな気孔が少い. 300 A 以上では, Needham 等2'が示しているように, 熔接中 クレーターに生ずる深い凹み (finger-type penetration) が熔融金属によって完全に埋められないため生ずると考 えられる不規則で大きな空洞を生じ易いととが確められ た.

\section{(5) その他}

Photo. 3 そ示すように, 一般に温度勾配の方向飞巨大な 柱状晶を示すが, 特に( b )のようと深い 'finger-type penetration’ の部分では急凝固のため, 母材熔加金属の泥合が 一様でなく，等温線の方向すなわち柱状晶と直角の方向に 成分濃度の差による縞が見られる、また 'finger-type' の 熔込の底は比較的不整であることが判る。これらは軟鋼 の母材にステンレスのビードを呿いた場合について既に Muir $\left.{ }^{6}\right)$ が示している所であって，アルミニウムの場合む 全く同様であることが認められたわけである. また試料の No. 12 にだけルート部にや」顕著なクラックが浔められ た.

\section{$\mathbf{V}$ と $め$}

MIG 熔接に括いて熔接条件を撰定するとは，次のよう な限定条件が存在することになる.

1. 下限電流 (threshold current), $1 / 16^{\prime \prime} \phi \mathrm{Al}: I>130 \mathrm{~A}$

2 . 上限電流 (defective current), " $\quad: I<300 \mathrm{~A}$

3. 設計脚長 $\quad(I / v)^{1 / 2}$

4. 適正有効熱入力 $5 \mathrm{mmAl}: I / \sqrt{v}>0.18 \times 10^{3}$ (fillet) これらを図で示せば Fig. 9 のようになる. 図中の平均脚 


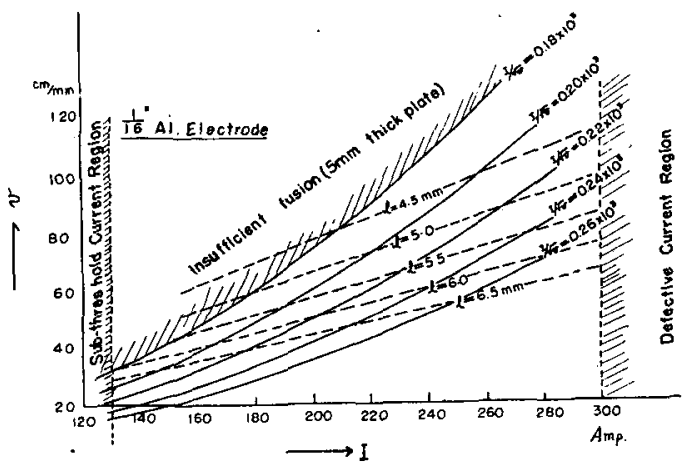

Fig. 9 Available welding condition defined by welding factors and variables

長 $l$ はig. 8 そ括ける実験值 $\left(l=0.5(I / v)^{1 / 2}-1.75\right)$ に よって計算したむのである. 以上の限定条件の下にさらに 気孔性, 跲込形状, 熔接歪, 作業性, 括よび場合伅よって は熱影響による材質の変化等を考慮して適当な揢接条件を 求めるのが，考光方としては合理的なやり方であるう.

以上について，5 mm 厚 $\mathrm{Al}(2 S)$ 板拓よび 1/16" $\phi \mathrm{Al}$

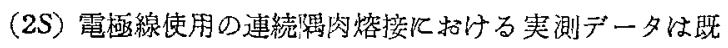
述の通りであるが，それらをまとめて実験の筙国で結諭的 なものを避べるならば次のようになる。

1. 熔接条件は例えば Fig. 9 に示したような限定条件 によって撰ぶべきであるが，\$4の Fig. $5,7,8$ 特よび気孔 性に関するデータは限られた場合についてが恃あるが，熔 接条件の合理的な設定と变北の程度の評洒に然与し得るで あるう。

2. 本試験炕括いては気泡性に関する絬果は不充分では むるが，Toeの近くに生じ易い大きな気沦を避けるために は, 比較的低い電流領域かまたは高い電流領域のいづれか を用いた方がよいようである. $5 \mathrm{~mm}$ 板に括いては削者は 隅肉脚長が它然的化過大沈る(Fig. 9) から，この場合 はガシをなるべくセットするかまたはガイド等を用いて，
比較的高い方の電流領域 $240 － 280 \mathrm{~A}$, 早い熔接速度 70 $110 \mathrm{~cm} / \mathrm{min},\left(I / \sqrt{v}=0.20 \sim 0.22 \times 10^{3}, l=4.5 \sim 5.5 \mathrm{~mm}\right)$ を 使用することが合理的であると考光られる。

3. finger-type penetration はやが狭くて等脚隅肉の場 合 $P_{s}^{\prime}$ (Fig. 6) 飞梳較的寄与が少く, 底が不整であり, 签融状態に和ける金属の混合が一様でなく，またしばしば 大きな空洞の原因とり舅い等から，少くと无まり厚く ない板の隅肉熔接では有用なものと見ない方がよいと考党 られる。

な招，本報告の試鈳は一系列のものに限られて扣り，特 に\$1，2飞論したような問題点の冭分な攻究に対しては， データが少く，板厚む溥すぎる悲がある，さらにアルミ合， 金の異る板厚, 線径, 材質扣よびアーク長さについてのデ 一タが增えることが希ましいと思われる, 終りと種々御意 見をいたがいた中樶室脣, 実験についてその協力に負う所 の極めて多い萩原健三氏感謝する次第である.

\section{文献}

1)内田，荻原；熔接学会誌 Vol. 25 ('56) No. 12, p. 660 .

2) Needham, Smith ; British W.J. 1958 No. 2, p. 66.

3) 渡辺, 佐藤; 熔接学会誌 Vol. 24 ('55) No. 12, p. 34

4）同上 ; 同上Vol. 26 ('57) No. 4, p. 33 ; その他

5）山内，中井；日立造船技報 Vol. 16 ('55) No. 1； No. 2,

6) Muir ; Britsh W.J. 1957 No. 7 p. 323.

7) Houldcroft \& Smith, Process Variables and Porosity in S.A.A. Welding, BWRA Symposium, 1955.

8) 内田, 䓇原; 燃接学会誌 Vol. 26 ('57) No. 11, p. 11.

9) Houldcroft \& Smith, British W.J. 1955 No. 2, p. 67.

10）鈴木，村瀕；熔接学会誌 Vol. 25 (56) No. 10, p. 521 ; 同 No. 11, p. 621. 